\title{
Undergraduates at a Research University Think of Faculty as Teachers and that Teaching is Prestigious
}

\author{
Teaching of Psychology, January 2020. https://doi-org/ 10.1177/0098628319888089
}

\section{Beth Morling ${ }^{1}$ and Jeong Min Lee ${ }^{2}$}

\author{
${ }^{1}$ University of Delaware; 105 The Green, Newark, DE, 19716 (morling@udel.edu) \\ ${ }^{2}$ Georgia State University; Atlanta, GA, 30302 (jlee500@gsu.edu)
}

What do university students understand about faculty work? Undergraduate (mostly first-year) students ( $N=$ 317) at a research university gave definitions of tenure, estimated how much time faculty spend teaching, and rated fictional faculty members. Students could define tenure but could not describe how it is earned or its role in academic freedom. Students overestimated the time faculty spend on teaching and underestimated time spent on research. Finally, students who assumed that fictional faculty taught more courses also assumed they had higher status. By comparison, faculty respondents $(N=645)$ who read the same fictional descriptions assumed higher teaching loads went with lower status markers. As they acculturate to life at a research university, first-year students could benefit from learning about faculty research roles and the value of academic freedom. ${ }^{1}$

Keywords: Stereotypes of teachers, student misconceptions, first-year students.

As students transition from high school to college, they face social and academic challenges (Upcraft, Gardner, \& Barefoot, 2005). Many are well-documented: Students face challenging coursework, less structured learning time, and larger class sizes than high school (Turner et al., 2017). In addition, students must learn how college professors differ from high school teachers. For example, high school faculty focus almost exclusively on teaching, while college faculty typically separate their work into the categories of research, teaching, and service (BrckaLorenz, Laird, Yuhas, Strickland, \& Fassett, 2018; Teichler, Arimoto, \& Cummings, 2013). New students at research universities may be unaware that for many faculty, the strongest expectation is to produce original scholarly research. New students who hold misconceptions about faculty work may be surprised if their professors are not good teachers or seem unavailable to them. In addition, without proper guidance, students could miss opportunities to participate in research their faculty are performing. The present article documents a few of these beliefs among firstyear students. If faculty learn about these misconceptions, they may be more effective at working with students through their college adjustment (Grossman, 1990).
We conducted a study of how students (mostly in their first year) at one research-intensive university understand tenure, faculty work, the status of teaching, and faculty title structures. The present report describes results pertaining to the first three aspects of that survey. A separate report (Morling \& Lee, this issue) presented the data collected on faculty title structures.

We investigated student knowledge of what tenure is and how one earns it; how much time professors spend on teaching, research, and other activities; and how students view teaching in terms of its status. We examined undergraduate students at an R1 institution (The Carnegie Classification of Institutions of Higher Education, n.d.).

Documenting first-year students' level of understanding of tenure, faculty time, and faculty work has potential applications. For one, if research university students expect faculty to spend most of their time teaching, they may be disappointed. They may expect all faculty to be regularly available (as their high school teachers probably were) and be engaging teachers who pay close attention to student success. Becoming aware of these expectations could motivate faculty, particularly those who teach first-year students, to change their own teaching or to clarify their roles in discussions with

\footnotetext{
${ }^{1}$ Correspondence concerning this article should be addressed to Beth Morling, University of Delaware 105 The Green, Newark DE, 19716. Contact: morling@udel.edu; 302.831.8377. We are grateful to Jingwei Wang for help coding responses. Full data sets and materials are available via the Open Science Framework (https://osf.io/ptvg4).
} 
students. For example, they can inform first-year students about the research that almost all faculty engage in. Faculty can explain why research is important for society and invite students to become involved. Indeed, students are more likely to become involved in research when they are informed about opportunities (Wayment \& Dickson, 2008). Students at large research universities, who are especially at risk for disengagement, benefit from peer-led programs that introduce them to faculty research, among other workshops (Whillans, Hope, Wylie, Zhao, \& Souza, 2018).

The present analyses were conducted in an exploratory fashion. However, anecdotally, new undergraduates scaffold their understanding of college on their high school experiences. For example, new students may refer to their faculty as "teachers" rather than "professors" and call them "Mr." or "Mrs." New students ask faculty advisors to add or drop courses for them, just as their guidance counselors once did. Such anecdotes lead us to predict that students will apply high school models to other aspects of faculty work (such as teaching load and tenure).

\section{Method}

The method for this study is reported in full in Morling and Lee (this issue). Only the details that are uniquely relevant to our questions about tenure, faculty time, and faculty work are described here.

\section{Participants}

The student sample was recruited from University of Delaware, a selective, public university that recruits students nationwide, with the majority from mid-Atlantic states. The university offers the Ph.D. and enrolls approximately 17,800 undergraduates and 3,700 graduate students, all at one main campus. About $80 \%$ of the student body takes General Psychology, and of these, about $75 \%$ elect research participation for a research requirement. We randomly selected 335 participants from the registered subject pool and invited them to participate online. (Table 1 in Morling \& Lee, this issue, depicts demographic characteristics.)

The faculty sample $(N=645)$ is described in Morling and Lee (2020).

\section{Academic Knowledge Questions}

We asked students to confirm the name of the university they attended. We then asked, "What kind of college or university best describes where you are enrolled right now as a student?" Response options are in Table 1.

We asked three, open-ended questions about tenure. First, "What does it mean for a faculty member at a university to have 'tenure?' Please write a definition of 'tenure' below. If you are not sure, please write what you think it might mean. If you have no idea at all, please write, 'I don't know.'” This question was followed by, "How confident are you in your answer to the previous question?", which was rated on a 100point sliding scale, with higher scores indicating more confidence. Second, we asked, "In general, what is the most important thing a faculty member at a university has to do in order to get tenure? Please write your understanding of the requirements for tenure, below." Third, "Why do faculty at universities value tenure as a policy? That is, why is tenure important? Please write one or two reasons below."

We coded answers to the three tenure questions using the following procedure. The first author read the responses and came up with categories for coding (see Table 2). Next, an undergraduate research assistant was trained on 50 of the responses. Two rounds of training reached good agreement, so the research assistant scored all of the remaining responses. To check interrater reliability, the first author also coded 60 randomly selected responses. Because some responses were coded into two categories, Cohen's kappas were computed with and /without a "missing" category: Definition of tenure = $.78 / .87$; Getting tenure .68/.78; Value of tenure $=.68 / .79$.

To measure students' perceptions of faculty teaching load, we asked, "How many courses per semester do you think the average, full time professor at the University of Delaware teaches? (1 course each semester, 1 or 2 courses per semester, up to 4 courses each semester $)^{1}$. The same question was asked again about Princeton University (the closest Ivy League university) and again about Delaware Technical and Community College (DTCC, the closest community college).

To measure students' perceptions of how faculty spend their time, we asked, "From your own perspective, what do you think the work week of a professor at your university (University of Delaware) ACTUALLY looks like? Students were asked to allocate percentages adding up to $100 \%$ to categories of doing original research, working with students, and attending meetings and campus events.

Students then answered the same question replacing "ACTUALLY" with the word "IDEALLY."

To measure what students think motivates a faculty career, we asked two questions: "Most people who become university professors did so because they love teaching", and "Most people who become university professors did so because they love doing research". Both were answered on a 7-point scale anchored from 1 (strongly disagree) to 7 (strongly agree) with $4=$ neither agree nor disagree.

The final question asked, "What do you think is the difference between a university professor who is called Assistant Professor from one who is called Associate Professor?" Students could select multiple response options, including tenure, Ph.D. attainment, and work hours (See Table 1 for response options).

\section{Procedure}

Informed consent and questionnaires were administered via Qualtrics. In the 30-minute study, undergraduate participants first answered the questions about their own university and about tenure. The questions about faculty time devoted to teaching, research, and service, appeared last. In the middle of the survey, questions about a fictional faculty member appeared (as reported in Morling and Lee, this issue).

We analyzed the results in JASP (JASP Team, 2017).

\section{Results}

We discuss results in the following order: 1) What do students understand about tenure at universities? 2) What are 
students' estimates of how professors spend their time? and 3) How do students view teaching in terms of its status for faculty?

\section{What Do Students Understand about Tenure at Universities?}

Results from coded responses to the tenure questions are in Table 2. A majority of students (60\%) accurately defined tenure as a guaranteed job. Many students gave a dictionary definition of tenure as simply holding a position (40\%), and some reported not knowing what tenure is (15\%). Students' mean confidence in their responses was 63.5 (out of 100) and confidence did not vary according to the definition they gave.

When asked how university faculty get tenure, only $9.5 \%$ indicated research or research quality. The most common response was that faculty simply have to work for a set number of years without incident (41\%), followed by being a good employee in general (34\%) or teaching well (21\%).

When asked why faculty members value tenure as a policy, only $3 \%$ mentioned academic freedom. The majority of students indicated that tenure is valuable mainly in terms of its definition: job permanence (55\%). Many students wrote that tenure brought extra prestige or economic benefits (48\%).

We also asked a closed-ended question about differences between faculty titles. Although $36 \%$ correctly answered that Associate Professors usually have tenure and Assistant Professors do not, only $7.6 \%$ of respondents correctly selected only this response; the rest also endorsed other, incorrect answers to the question.

\section{How Do Students Think Faculty Spend Their Time?}

On average, students estimated that faculty teach 3 courses per semester (see Table 1), which is an overestimate. Tenure-track faculty at the University of Delaware actually teach about 3 courses per year in the sciences and about 4 courses in the humanities, a figure that includes graduate courses.

Student estimates of the teaching load at Princeton-an Ivy-League university UD students consider to be more prestigious than UD-was also 3 courses per semester. Their estimate for the nearby community college (DTCC, a college UD students consider to be less prestigious) was actually lower, between 2 and 3 courses per semester. We compared these differences in estimated teaching load using dependent $t$-tests. These estimates were statistically significant ( $t_{\mathrm{UD}}$ to Princeton $(314)=2.89, p=.004, d=.16,95 \% \mathrm{Cl}\left[0.052,0.274 ; t_{\mathrm{UD}}\right.$ to DTCC $(314)=6.98, p<.001, d=.39,95 \% \mathrm{Cl}[0.278,0.507])$.

Students estimated that UD faculty actually spend about half of their time teaching (49.4\%) with about $26.5 \%$ on research and $19 \%$ on committee work. Students said that ideally, faculty should spend a bit more time on teaching $(54.8 \%)$ and a bit less on research (24.8\%).

When asked why faculty become professors, students said that it was because faculty loved both teaching $(M=4.84)$ and research $(M=5.03)$. Both items were rated higher than the scale midpoint. Research was rated barely higher than teaching, $t(311)=2.17 p=.03, \mathrm{~d}=-.11,95 \% \mathrm{Cl}[-0.234,-0.011]$.

\section{Do Ratings Depend on Student Experience?}

So far, the data support the interpretation that students in our sample are unfamiliar with what tenure is or how much faculty usually teach. We explored the possibility that subgroups of students were more accurate about these issues. We conducted a series of independent groups $t$-tests on the dependent variables in Table 1, comparing different types of students, as follows.

First, we compared students who had correctly answered the type of university they attended (a doctoral-granting university) to those who answered this question incorrectly or did not know. All of the confidence intervals included zero, indicating that correct students were not more likely to know what tenure was, know a UD faculty member's teaching load, or believe that UD faculty should spend less time teaching.

Second, we compared fall students (more of whom were new first-years) to spring students. Again, all of the confidence intervals included zero.

Third, we correlated the number of semesters students had completed with the main dependent variables. We found that the more semesters students had completed, the lower their estimates of UD and Princeton teaching loads, but these two correlations were weak, $r(314)=-.13, p=.03,95 \% \mathrm{Cl}[-$ $.016,-.234] ; r(314)=-.13, p=.03,95 \% \mathrm{Cl}[-.016,-.234]$. Number of completed semesters was not correlated with any other variables. (However, there were only a few students with more than 2 semesters of experience, so this estimate is unstable.)

Overall, the results suggest that relatively more experienced students did not have more accurate information about faculty work.

\section{How Do Students View the Status of Teaching?}

We conducted a series of simple regressions to explore what qualities students associated with a professor's teaching load. These analyses were conducted post-hoc and should be viewed as preliminary.

We analyzed student ratings of a fictional faculty member (see Morling \& Lee, this issue), combining across six possible targets because mean student ratings did not differ (as reported there, students treated all six targets the same). We used estimated teaching load of the target to predict other ratings of the target. Students estimated the target's teaching load before rating other variables in this analysis, suggesting that teaching load estimates may have influenced the other ratings, rather than the reverse.

As seen in Table 3, the higher the teaching load students assumed for the fictional faculty target, the higher students estimated the target's salary to be. In addition, the higher the teaching load, the more likely they thought the target had a Ph.D., had tenure, was liked and respected by colleagues, and the more they thought the target had published scholarship.

When we conducted the same analyses for faculty respondents, we found a different pattern. In general, faculty estimates of a higher teaching load were associated with ratings lower in prestige. The higher a teaching load that a faculty respondent estimated for the target, the lower they 
estimated the target's salary to be, and the less likely the target was thought to have a Ph.D., to have tenure, to be liked by colleagues, to be respected by colleagues outside the university, or to have published scholarship recently. The differences in slopes for students and faculty were statistically significant as tested by the interaction term in a regression (see Table 3). ${ }^{2}$

Next, we used teaching load to predict student and faculty respondents' rated feelings toward the fictional faculty member. The higher the teaching load students estimated, the more they reported "liking" and "respecting" the target. In contrast, for faculty respondents, the higher the estimated teaching load, the less they reported "envying" and "feeling sorry" for the target (faculty liking and respect were uncorrelated with estimated teaching load; see Table 3).

\section{Discussion}

Effective teaching involves knowing the misconceptions that students hold so we can address and correct them (Sadler, Sonnert, Coyle, Cook-Smith, \& Miller, 2013; Shulman, 1986). The present study documented several misconceptions that first-year students hold about faculty work at research universities. The first misconception concerns tenure: Students do not understand what tenure means at a research university. Rather than knowing that tenure is awarded for scholarly achievements and is intended to protect academic freedom, students assumed tenure is awarded based on longevity of employment or teaching ability. Faculty might address these misconceptions with students. Even at baccalaureate colleges, where teaching usually is more important for tenure, faculty could find it useful when they advise students for Ph.D. programs or academic careers.

Our study found that students believe tenure is primarily beneficial because of its job security. Indeed, tenure promotes a stable workforce that is a basis for student engagement and faculty development (AAUP, 2014; Kezar \& Maxey, 2016). However, almost no students recognized that tenure was also designed to protect academic freedom. Even in K-12 systems, tenure was historically established to protect teachers who speak out about educational or political issues or who fail to support particular political candidates (Kahlenberg, 2015). This gap in student knowledge suggests that the benefits and qualifications for tenure could be an enlightening topic of discussion, perhaps in a first-year seminar. Faculty who work with first-year students should consider spending a session discussing power dynamics in research, intellectually driven protest, and the life of the mind.

A second misconception in our student sample relates to teaching. Students recognized that faculty conduct research and that faculty became professors because they enjoy research. However, they underestimated the time faculty spend on this endeavor and thought they should dedicate less of their time to research. Students believed that faculty at their research university spend about half of their time teaching, thought faculty should spend even more of their time on teaching, and estimated that faculty teach around 6 courses per year. Informing students of faculty research-perhaps by posting one's laboratory or writing hours next to office hourscan further inform students about the multiple roles of university faculty. Posting recent publications or conference posters in the hallways can also advertise the research work that faculty and students do.

According to one analysis (Barefoot, 2005), many of the courses that first-year students take (e.g., introductory psychology, biology, history, and math) are taught by senior faculty who likely have research careers. Nevertheless, because students mainly encounter faculty in classrooms, faculty members' research lives remain hidden. Faculty who teach introductory courses might use a bit of class time to incorporate references to the research programs of themselves and their colleagues. Such examples can convey how knowledge is not a static body of information, but a continually developing process. In addition, informing introductory students about how to become involved in university research casts a broader, more inclusive net for these valuable experiences.

Third, students misperceive the value of teaching in the academy. Students who thought that a fictional faculty member taught more courses also rated that person as having more prestige in terms of salary, Ph.D. attainment, and being respected by others. In contrast, faculty respondents who believed a fictional faculty member taught more courses also thought the person had less prestige (in fact, a more accurate belief; Monks, 2004). The fact that students assumed that a community college professor teaches less than a professor at an Ivy League university is also consistent with their misconception that teaching is associated with prestige (readers of the journal Teaching of Psychology may not wish to correct this particular student misconception!). Nevertheless, students, especially those interested in academic careers, should learn about the balance of teaching and research roles across types of institutions.

Student understanding of faculty work was at odds with the conventional reality of a modern research university. At most research universities, there are nontenure-track faculty who are teaching-focused; they have higher teaching loads and are not typically expected to do research. Such faculty actually do fulfill the perception of a "professor" held by students in our study. In reality, however, they are institutionally marginalized by having lower-status, tagged titles, lack of access to tenure, lower pay and sometimes lack of access to faculty governance (Kezar \& Maxey, 2016). Ironically, at research universities, the subgroup of faculty who come closest to what the students expect are actually further from what academic culture sees as the ideal.

\section{Limitations}

We collected data on only one campus so it is unclear whether we'd find similar results at a different research university. We also do not expect results to generalize to students at a baccalaureate or community college, where faculty actually are more likely to spend time on, and be 
promoted based on, quality teaching. Indeed, in these contexts, student beliefs will be less discrepant from reality.

Some of our analyses (namely the correlational analyses of teaching load and prestige) were conducted in an exploratory mode and need to be replicated in a new sample. In addition, we did not manipulate the teaching loads of the fictional faculty, so a future study could establish that teaching load causes ratings of prestige (rather than the reverse).

One conclusion was that students overestimate the actual amount of time that faculty at UD spend teaching. This is an overestimation because UD's tenure-track faculty (who make up $80 \%$ of the faculty at UD) spend at least $40 \%$ of their time on research (and even higher in the sciences). However, perhaps students were thinking about UD's nontenure-track faculty, who typically do teach 3 or 4 courses per semester, which takes up about $87 \%$ of their time. If student respondents were basing their estimates on these faculty, then their estimates are more accurate. However, this interpretation does not fit with three other results, namely that students were incorrect about the nature of tenure; they overestimated how many classes Princeton faculty probably teach; and they assumed teaching more was associated with earning more money and prestige.

\section{Applications: Knowledge Gaps to Fill}

Our results point to several knowledge gaps that faculty at research universities could strive to fill. First, if faculty at research universities inform first-year students about how central research is to faculty work, students might gain a greater appreciation for basic science and humanities scholarship. Such appreciation might eventually translate into greater citizen support of research universities. Some state legislatures have proposed requiring faculty to teach a certain number of courses or hold certain number of office hours per week (Richmond, 2017). When the general public complains about how little professors appear to "work," their anger could be based, in part, on the fact that they expect faculty to be primarily teachers. Faculty can attempt to address this misconception no matter where they teach, raising awareness that universities are research centers that benefit society. Students, as well, gain multiple skills when they participate in faculty research (Landrum \& Nelsen, 2002); therefore, learning about research early may encourage even more students to seek these experiences (Wayment \& Dickson, 2008).

A second implication of our data is that if research faculty are not meeting students' teaching expectations, students could feel especially aggrieved because their expectations have been let down. In fact, the teaching expectations of firstyear students could partly explain the lower engagement of students at research universities (NSSE, 2017), an assumption testable in a future study. Some research faculty may be motivated to improve their teaching to meet student expectations. Another way to address the gap between incentives for teaching and students' expectations is to emphasize the role of teaching in apprentice-style laboratory settings.
Our hope is that with faculty leadership, first-year students at research universities can become informed about the roles of scholarship, teaching, and values such as academic freedom in their new educational context (Upcraft et al., 2005). They can appreciate how research universities not only transmit knowledge but also strive to create new knowledge in a free exchange of ideas. Awareness could empower students to develop their own scholarly ideas or join a faculty research lab. Learning about academic freedom could inspire students to develop their own viewpoints and protect the expression of others. Future studies can explore ways students benefit as they learn more about what research university faculty really do.

\section{Footnotes}

${ }^{1}$ The intervals between each level of this variable were equivalent-about 0.5 courses per semester apart-so we treated this as an interval-level, rather than ordinal, variable. Specifically, $1=1$ course per semester; $2=1$ to 2 courses per semester, $3=2$ courses per semester, $4=2$ to 3 courses per semester, $5=3$ courses per semester, $6=3$ to 4 courses per semester, 7 = 4 courses per semester.

2 The regression results presented in Table 3 were pooled across the six randomly assigned faculty targets. However, because the faculty sample showed mean differences in ratings across the six targets, it was important to ensure that these correlational patterns held within each faculty target condition. Therefore, we followed the pooled regressions with two alternatives. First, we tested each dependent variable in a hierarchical model (using Mixed Models in SPSS) and inspected the Sample $X$ Teaching load interactions when respondents were nested within the six faculty target conditions. All interactions in Table 3 were the same. Second, we conducted the Sample X Teaching load interactions separately within each of the six faculty targets (using Split File in SPSS). This is a less powerful approach, so the interactions were not always statistically significant; however, they were usually in the same direction as those reported in Table 3 . In sum, we are reasonably confident that the regression results in Table 3 are not simply attributable to average differences among faculty targets detected by the faculty sample. Details of these two analyses will be made available on the Open Science Framework.

\section{References}

AAUP (2014). Contingent appointments and the academic profession. Standing committee and subcommittee reports. Downloaded from https://www.aaup.org/report/contingentappointments-and-academic-profession

Barefoot, B. O. (2005). Current institutional practices in the first college year. In M. L., Upcraft, J. N. Gardner, \& B. O. Barefoot (Eds.), Challenging and supporting the first-year 
student: A handbook for improving the first year of college (pp. 47-66). Indianapolis, IN: Jossey-Bass.

BrckaLorenz, A., Laird, T. N., Yuhas, B., Strickland, J., \& Fassett,K. (2018). Faculty types and effective teaching: A cautionary exploration of how faculty spend their time. Paper presented at the 2018 annual meeting of American Educational Research Association (AERA), New York, NY.

Grossman, P. L. (1990). The making of a teacher: Teacher knowledge and teacher education. New York, NY: Teachers College Press.

JASP Team (2017). JASP (Version 0.8.4) [Computer software]. Retrieved from https://jasp-stats.org

Kahlenberg, R. D. (2015, Summer). How due process protects teachers and students. American Educator (online edition) Downloaded from https://www.aft.org/ae/summer2015/kahlenberg .

Kezar, A., \& Maxey, D. (2016). Recognizing the need for a new faculty model. In A. Kezar and D. Maxey (Eds.), Envisioning the faculty for the $21^{\text {st }}$ century: Moving to a mission-oriented and learner-centered model (pp. 23-41). New Brunswick, NJ: Rutgers University Press.

Landrum, R. E., \& Nelsen, L. R. (2002). The undergraduate research assistantship: An analysis of the benefits. Teaching of Psychology, 29, 15-19. http://dx.doi.org/10.1207/S15328023TOP2901 04

Monks, J. (2004). The relative earnings of contingent faculty in higher education (CHERI Working Paper \#59). Retrieved from Cornell University, ILR School site: http://digitalcommons.ilr.cornell.edu/ cheri/22/

Morling, B. \& Lee, J.M. (2020). Are "Associate Professors" better than "Associate Teaching Professors"? Student and faculty perceptions of professorial titles. Teaching of Psychology, 47(1), 50-57. https://doiorg.udel.idm.oclc.org/10.1177/0098628319888087

.National Survey of Student Engagement (NSSE). (2017). Engagement insights: Survey findings on the quality of undergraduate education. NSSE Annual results 2017. Bloomington: Indiana University. Downloaded from http://nsse.indiana.edu/html/annual_results.cfm
Richmond, T. (2017, March 21). Republicans press professors to spend more time teaching. The Associated Press. Retrieved from https://www.apnews.com/b1dae077aba843a888b3516 b4c5769e7

Sadler, P. M., Sonnert, G., Coyle, H. P., Cook-Smith, N., \& Miller, J. L. (2013). The influence of teachers' knowledge on student learning in middle school science classrooms. American Educational Research Journal, 50, 1020-1049. doi: 10.3102/0002831213477680

Shulman L. (1986). Those who understand: Knowledge growth in teaching. Educational Researcher, 15, 4-14. doi: http://www.jstor.org/stable/1175860 .

Teichler, U., Arimoto, A., \& Cummings, W. K. (2013). The changing academic profession: Major findings of a comparative survey. Philadelphia, PA: Springer.

The Carnegie Classification of Institutions of Higher Education (n.d.). About Carnegie Classification. Retrieved from http://carnegieclassifications.iu.edu/.

Turner, R., Morrison, D., Cotton, D., Child, S., Stevens, S., Nash, P., \& Kneale, P. (2017). Easing the transition of first year undergraduates through an immersive induction module, Teaching in Higher Education, 27, 805-821. Doi: 10.1080/13562517.2017.1301906

Wayment, H. A., \& Dickson, K. L. (2008). Increasing student participation in undergraduate research benefits students, faculty, and department. Teaching of Psychology, 35, 194-197. Doi: 10.1080/00986280802189213

Whillans, A. V., Hope, S. E., Wylie, L. J., Zhao, B., \& Souza, M. J. (2018). A program to improve student engagement at research-focused universities. Teaching of Psychology, 45, 172-178. Doi: 10.1177/0098628318762905

Upcraft, M. L., Gardner, J. N., \& Barefoot, B. O. (Eds.) (2005). Challenging and supporting the first-year student: $A$ handbook for improving the first year of college. Indianapolis, IN: Jossey-Bass 
Table 1 What do students believe about faculty work? $(\mathrm{N}=317)$

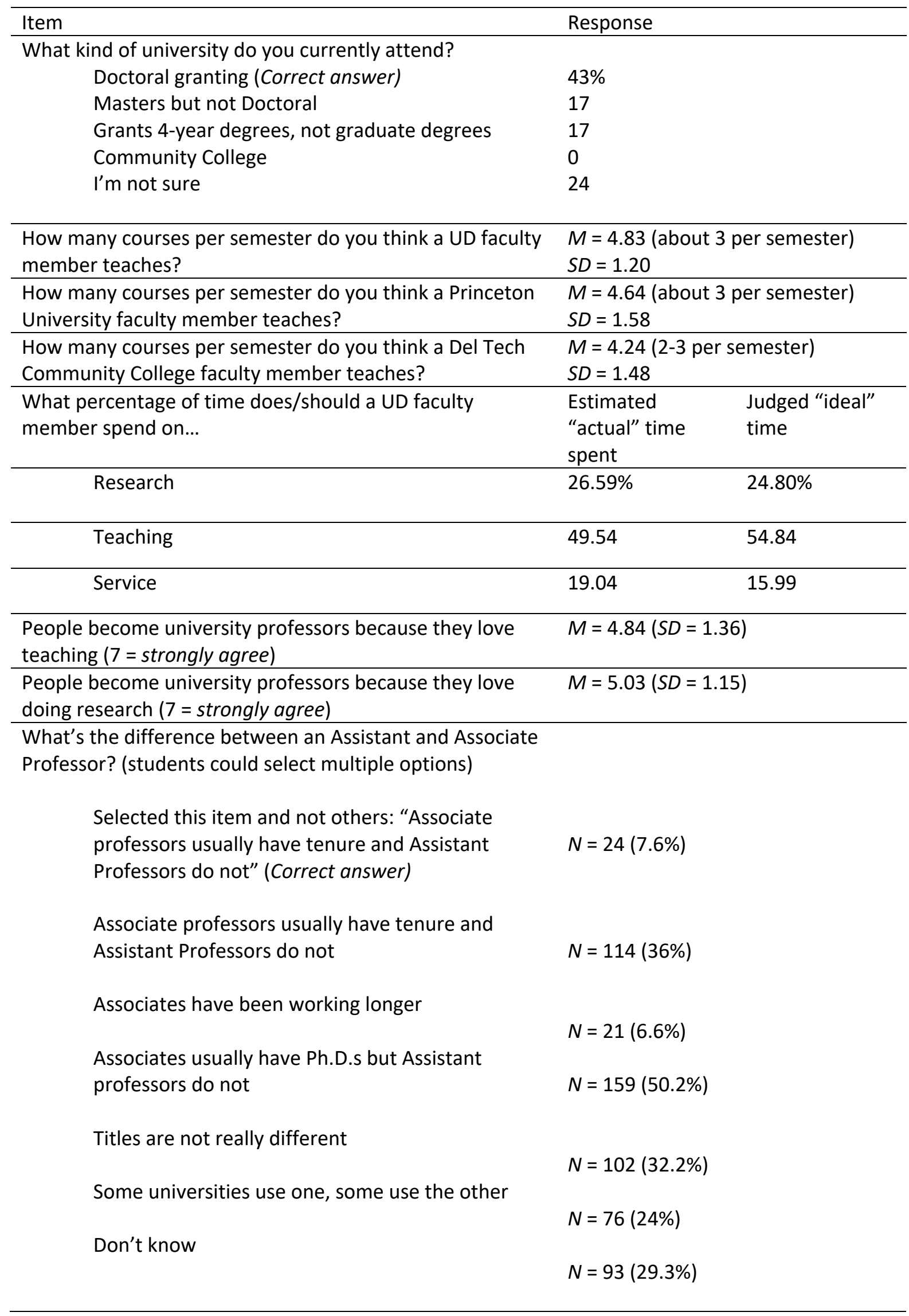


Table 2 What do students believe about tenure at the university?

\begin{tabular}{|c|c|c|}
\hline Coding Categories & Example responses by students & $\begin{array}{l}\text { Percent of } \\
\text { students } \\
\text { mentioning } \\
\text { this category }\end{array}$ \\
\hline \multicolumn{3}{|l|}{ What is tenure? } \\
\hline Job permanence & $\begin{array}{l}\text { "They are guaranteed a position no matter } \\
\text { what" }\end{array}$ & $59.9 \%$ \\
\hline $\begin{array}{l}\text { Holding/being in a } \\
\text { position }\end{array}$ & "Holding an office or position" & 39.1 \\
\hline Don't know & & 14.5 \\
\hline Something else & $\begin{array}{l}\text { "A job with full-time benefits" } \\
\text { "Being paid after you're retired" } \\
\text { "To make more money" } \\
\text { "A professor has shown success" }\end{array}$ & 19.9 \\
\hline $\begin{array}{l}\text { Self-rated confidence in } \\
\text { tenure definition (100 point } \\
\text { scale) }\end{array}$ & & $\begin{array}{l}M=63.54 \\
S D=26.18\end{array}$ \\
\hline \multicolumn{3}{|l|}{$\begin{array}{l}\text { How do faculty at UD get } \\
\text { tenure? }\end{array}$} \\
\hline Research quality & $\begin{array}{l}\text { "They have to be a good professor and also } \\
\text { publish/work in their field" }\end{array}$ & $9.5 \%$ \\
\hline Teaching quality & "Be a helpful and caring teacher" & 20.5 \\
\hline $\begin{array}{l}\text { Being in the job a } \\
\text { certain number of } \\
\text { years }\end{array}$ & $\begin{array}{l}\text { "They have to work for the university for a } \\
\text { certain amount of time" }\end{array}$ & 40.7 \\
\hline $\begin{array}{l}\text { Being a good } \\
\text { employee in general }\end{array}$ & "Be dedicated to excellence" & 34.4 \\
\hline Don't know & & 13.2 \\
\hline \multicolumn{3}{|l|}{ Why is tenure valued? } \\
\hline $\begin{array}{l}\text { Allows academic } \\
\text { freedom }\end{array}$ & $\begin{array}{l}\text { "Tenure is important because they have } \\
\text { more freedom with what they can do" }\end{array}$ & $3.2 \%$ \\
\hline $\begin{array}{l}\text { You can't get } \\
\text { fired/always have a } \\
\text { job }\end{array}$ & "It gives them job security" & 54.6 \\
\hline Don't know & & 12.3 \\
\hline $\begin{array}{l}\text { Mentions salary, } \\
\text { benefits, prestige, } \\
\text { respect }\end{array}$ & $\begin{array}{l}\text { "It means that they are respected" } \\
\text { "They get paid more money" } \\
\text { "So we have qualified people teaching the } \\
\text { students" } \\
\text { "Recognizes the faculty that deserve it" }\end{array}$ & 47.9 \\
\hline
\end{tabular}

Note. Percents do not add to 100 because answers were occasionally coded in multiple categories. 
Table 3 Correlates (simple slope beta estimates) of faculty and student estimates of a fictional faculty member's teaching load.

\begin{tabular}{|c|c|c|c|}
\hline \multirow[b]{2}{*}{$\begin{array}{l}\text { Association between } \\
\text { estimated teaching load and } \\
\text { estimated.... }\end{array}$} & \multicolumn{2}{|c|}{ Ratings by: } & \multirow[b]{2}{*}{$\begin{array}{l}\text { Are slopes significantly } \\
\text { different? } \\
\text { Interaction term } \\
\text { (Faculty }=0)\end{array}$} \\
\hline & $\begin{array}{l}\text { Faculty } \\
\text { (beta, } N=652 \text { ) }\end{array}$ & $\begin{array}{l}\text { Students } \\
\text { (beta, } N=314 \text { ) }\end{array}$ & \\
\hline Salary & $-.191^{*}$ & $.328^{*}$ & $1.05^{*}$ \\
\hline $\begin{array}{l}\text { Likelihood of holding the } \\
\text { Ph.D. }\end{array}$ & $-.319^{*}$ & $.392 *$ & $1.44^{*}$ \\
\hline Likelihood of having tenure & $-.436^{*}$ & $.237 *$ & $1.36^{*}$ \\
\hline $\begin{array}{l}\text { Liked by colleagues inside } \\
\text { the university }\end{array}$ & $-.317^{*}$ & $.147^{*}$ & $0.94 *$ \\
\hline $\begin{array}{l}\text { Respect from colleagues } \\
\text { inside the university }\end{array}$ & .076 & $.213^{*}$ & $0.28^{*}$ \\
\hline $\begin{array}{l}\text { Respect from colleagues } \\
\text { outside the university }\end{array}$ & $-.321^{*}$ & $.213^{*}$ & $1.08^{*}$ \\
\hline Published scholarship recently & $-.108^{*}$ & $.216^{*}$ & $0.66^{*}$ \\
\hline \multicolumn{4}{|l|}{$\begin{array}{l}\text { Association between } \\
\text { estimated teaching load and } \\
\text { answers to: }\end{array}$} \\
\hline I like this person & -.054 & .103 & $0.32 *$ \\
\hline I respect this person & .041 & $.161^{*}$ & 0.24 \\
\hline I envy this person & $-.077^{*}$ & $.109 *$ & $0.38^{*}$ \\
\hline I feel sorry for this person & $-.120 *$ & -.041 & 0.16 \\
\hline
\end{tabular}

Note: In the first two columns, * indicates slopes that a Faculty or Student slope is significantly different from zero $(p<.05)$. In the third column, * indicates the Faculty and Student slopes are significantly different from each other $(p<.05)$. 